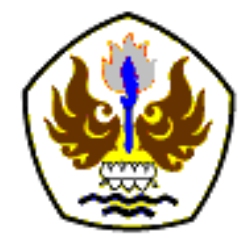

INFOMATEK

Volume 18 Nomor 1 Juni 2016

\title{
PERANCANGAN PERANGKAT LUNAK PEMANTAU LOKASI ANAK BERBASIS ANDROID
}

\author{
Wanda Gusdya Purnama* \\ Program Studi Teknik Informatika \\ Fakultas Teknik - Universitas Pasundan
}

\begin{abstract}
Abstrak: Pada piramida kebutuhan, rasa aman termasuk pada kebutuhan primer, setelah kebutuhan fisiologi (seperti sandang, pangan, dan papan) terpenuhi. Untuk hal jaminan rasa aman, Indonesia bukanlah negara yang terbaik, dan tidak terlalu baik. Berdasarkan data crime index dan safety index yang dikeluarkan oleh Numbeo, Kaum yang paling banyak menjadi target kriminal adalah wanita dan anak-anak. Berbagai langkah pencegahan dilakukan, seperti membekali wanita dan anak-anak dengan kemampuan membela diri. Namun, kadang kemampuan membela diri saja tidak cukup, jika yang dihadapi adalah pelaku tindak kriminal yang berkelompok. Dengan memanfaatkan smartphone dengan sistem operasi android dan location based service, dimungkinkan untuk membuat teknologi pemantauan lokasi anak dan anggota keluarga lainnya dengan menerapkan konsep gamifikasi. Hasil akhir penelitian ini adalah sebuah rancangan perangkat lunak pemantau lokasi anak berbasis android.
\end{abstract}

Kata kunci : Gamifikasi, Location Based Service, Android, Perangkat Lunak

\section{PENDAHULUAN}

\subsection{Latar Belakang}

Manusia memiliki lima tingkat kebutuhan hidup yang akan selalu berusaha untuk dipenuhi sepanjang masa hidupnya. Kebutuhan tersebut berjenjang dari yang paling mendesak hingga yang akan muncul dengan sendirinya saat kebutuhan sebelumnya telah dipenuhi. Setiap orang pasti akan melalui tingkatan-tingkatan itu, dan dengan serius berusaha untuk memenuhinya, namun hanya sedikit yang mampu mencapai tingkatan tertinggi dari piramida pada Gambar 1 (Maslow [1]).

Pada piramida tersebut, rasa aman termasuk pada kebutuhan primer, setelah kebutuhan fisiologi (seperti sandang, pangan, dan papan) terpenuhi. Setelah seseorang merasa kenyang, orang tersebut tidak akan memikirkan makanan lagi. Orang tersebut akan memikirkan tingkatan berikutnya pada piramida kebutuhan, yaitu rasa aman. Rasa aman atau keamanan inilah yang mendasari penelitian ini.

\footnotetext{
*) wanda.gusdya@unpas.ac.id
} 


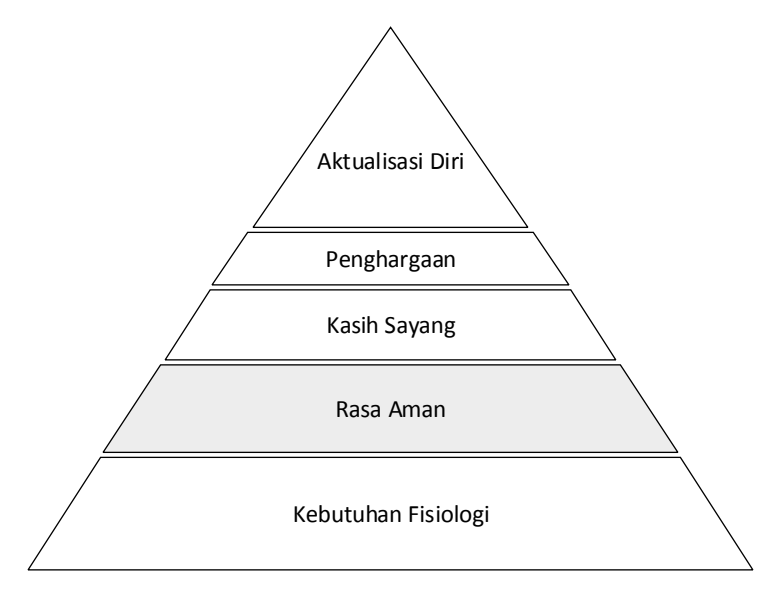

Gambar 1(a).

Piramida Kebutuhan Manusia menurut Abraham Maslow [1]

Untuk hal jaminan rasa aman, Indonesia bukanlah negara yang terbaik, dan tidak terlalu baik. Berdasarkan data crime index dan safety index yang dikeluarkan oleh Numbeo, database kota dan negara online terbesar, Indonesia menempati urutan ke 80 (sampai dengan Maret 2015) negara yang paling aman tahun 2015, dengan poin crime index 47,22 dan safety index 52,78 (Anonim [2]). Poin tersebut didasarkan pada tingkat kriminalitas, peningkatan tindak kriminal, tingkat keamanan di siang hari, tingkat keamanan di malam hari, kekhawatiran terhadap pembobolan rumah, kekhawatiran terhadap pencurian, kekhawatiran terhadap pencurian kendaraan, kekhawatiran terhadap pencurian benda pada kendaraan, kekhawatiran terhadap penyerangan, kekhawatiran terhadap penghinaan, kekhawatiran terhadap diskriminasi (terhadap Suku Agama Ras dan Antar- golongan), permasalahan narkotika dan obatobatan terlarang, permasalahan kejahatan atas properti, permasalahan kejahatan dengan kekerasan, dan permasalahan penyuapan.

Menurut data Badan Pusat Statistik (BPS), pada tahun 2013, jumlah tindak pidana (kriminal) di seluruh Indonesia adalah 342.084. Jawa Barat menempati peringkat ketiga dengan 24.843 tindak pidana, dibawah DKI Jakarta (49.498) dan Sumatera Utara (40.709) (Anonim [3]). Masih menurut BPS, di Indonesia, penyelesaian tindak pidana hanya mencapai $52,92 \%$ pada tahun 2013 (Anonim [4]).

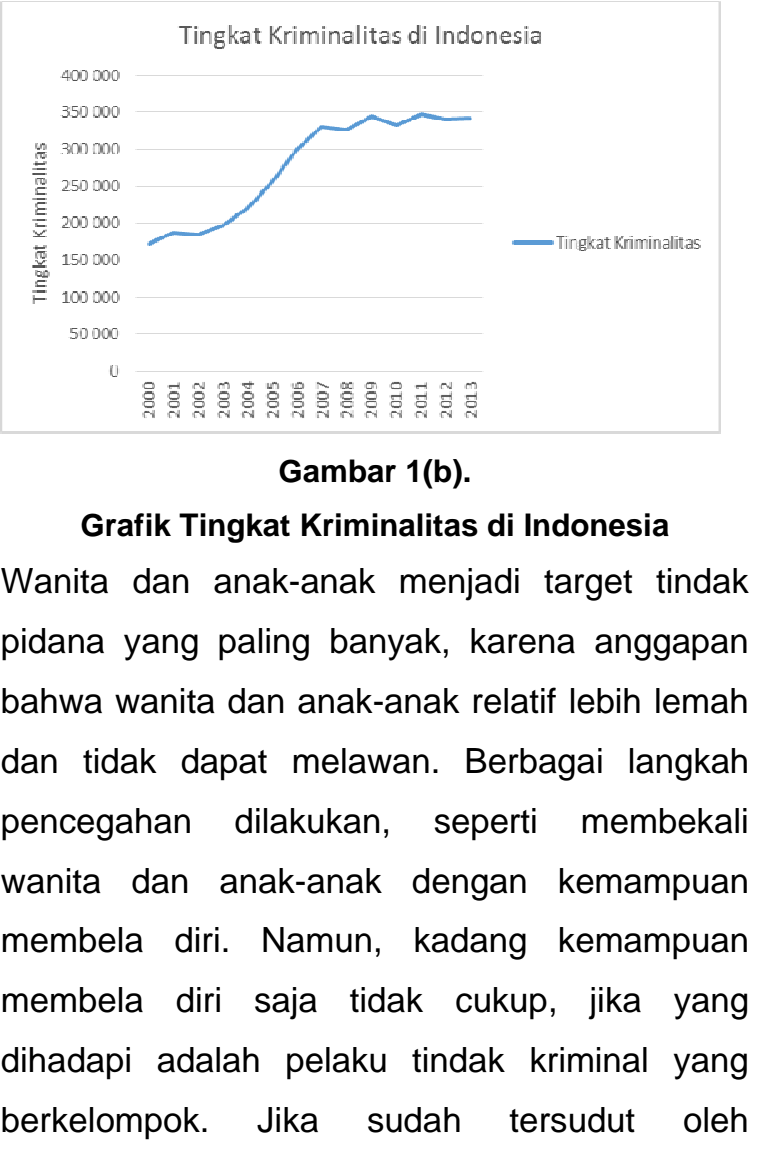


kelompok pelaku tindak kriminal, korban harus mencari bantuan. Sejak penggunaan kentongan, teknologi informasi berperan penting pada proses pemantauan lokasi anak tersebut. Dengan memanfaatkan smartphone dengan sistem operasi android dan location based service, dimungkinkan untuk membuat teknologi pemantauan lokasi untuk anak-anak dalam sebuah keluarga dengan menerapkan konsep gamifikasi.

\subsection{Identifikasi Masalah}

Berdasarkan pada hal-hal tersebut diatas, maka dirumuskan beberapa identifikasi masalah sebagai berikut:

1. Bagaimana merancang perangkat lunak pemantau lokasi anak berbasis android.

2. Bagaimana merancang konsep gamifikasi untuk perangkat lunak pemantau lokasi anak berbasis android.

\subsection{Tujuan Penelitian}

Berikut ini merupakan tujuan dari penelitian yang dilakukan:

1. Merancang perangkat lunak pemantau lokasi anak berbasis android.

2. Merancang konsep gamifikasi untuk perangkat lunak pemantau lokasi anak berbasis android.

\section{METODOLOGI}

Metode yang digunakan untuk penelitian pada pembangunan perangkat lunak pemantau lokasi anak dengan menggunakan metode location based service berbasis android terdiri dari beberapa kegiatan yang dilakukan untuk lebih jelasnya dapat dilihat pada Gambar 2(a).

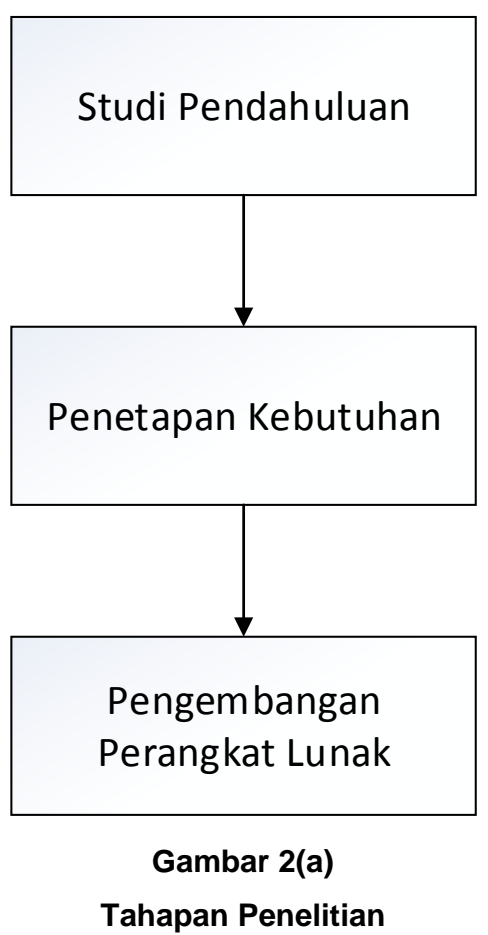

\subsection{Studi Pendahuluan}

Kegiatan ini diawali dengan mempelajari penelitian dan perangkat lunak yang serupa dan berkaitan dengan perangkat lunak yang dikembangkan.

\section{Penetapan Kebutuhan}

Kebutuhan perangkat lunak (Software Requirement) merupakan keterkaitan dengan elisitasi, analisis, spesifikasi, dan validasi persyaratan perangkat lunak serta manajemen persyaratan selama siklus hidup seluruh produk perangkat lunak. Sedangkan, Spesifikasi 
Kebutuhan Perangkat Lunak (Software Requirement Specification) merupakan dokumentasi produksi produk yang dapat ditinjau secara sistematis, dievaluasi, dan disetujui. Pada fase ini dilakukan penetapan kebutuhan-kebutuhan yang akan disyaratkan agar perangkat lunak dapat memenuhi tujuan penelitian.

\section{Pengembangan Perangkat Lunak}

Siklus Hidup Pengembangan Perangkat Lunak atau Software Development Life Cycle (SDLC) merupakan sebuah aturan yang digunakan dalam Sistem Rekayasa, Sistem Informasi, dan Rekayasa Perangkat Lunak untuk menggambarkan sebuah proses saat Perencanaan, Pembuatan, Pengujian, dan Penyebaran (Deployment) sebuah sistem informasi. SDLC terdiri dari beberapa tahap yaitu:

1. Analisis, tahap pengumpulan data seperti lingkup, batasan, kebutuhan awal sistem/aplikasi, dan perencanaan pembangunan yang akan dilakukan.

2. Desain, tahap perancangan aplikasi seperti perancangan antar muka aplikasi, interaksi pengguna dengan aplikasi, perancangan struktur program, dan perancangan database.

3. Kontruksi, tahap pembangunan aplikasi berdasarkan dari disain yang sudah dibuat.

4. Pengujian, tahap menguji aplikasi yang bertujuan untuk mengetahui respon aplikasi saat pengguna menyisipkan data, mencari kesalahan dalam pemrosesan data, dan menverifikasi aplikasi sudah sesuai dengan kebutuhan atau belum.

5. Implementasi, tahap penerapan aplikasi yang siap digunakan oleh pengguna, dan telah lolos dari tahap pengujian.

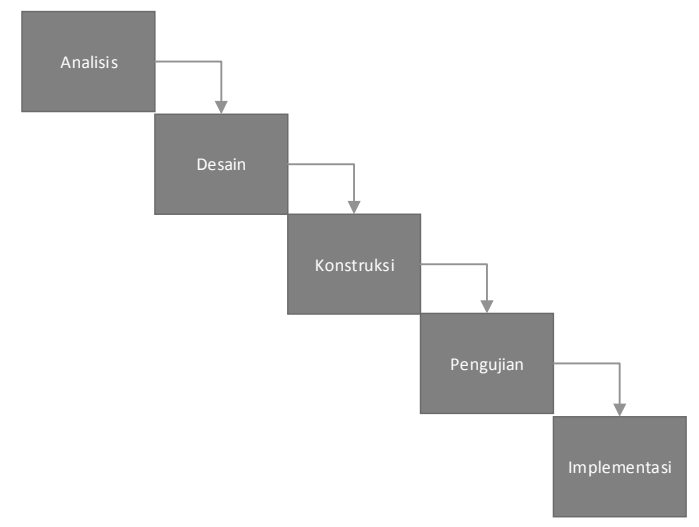

Gambar 2(b).

Metodologi Software Development Life Cycle (SDLC)

Pada penelitian ini, penulis hanya melakukan tahapan analisis dan desain perangkat lunak, yang akan menghasilkan rancangan perangkat lunak yang disiapkan untuk fase konstruksi.

\section{LANDASAN TEORI}

\section{Definisi Gamifikasi}

Gamifikasi (Gamification) adalah sebuah strategi bisnis yang mengaplikasikan teknik perancangan permainan (game) pada produk non-game untuk mengendalikan perilaku konsumen (Anonim [5]). 
Contoh-contoh awal gamifikasi didasarkan pada poin bermanfaat untuk orang yang memiliki pengalaman pada platform berbasis lokasi seperti fitur Facebook's "Place", foursquare, dan Gowalla. Beberapa teknik meliputi:

a. achievement "badges"

b. achievement levels

c. "leader boards"

d. sebuah "progress bar" atau visual lainnya untuk menunjukkan bagaimana orang-orang dekat mendapatkan penghargaan atas seringnya mereka belanja di tempat tertentu.

e. virtual currency

f. sistem untuk awarding (pemberian hadiah), redeeming (penebusan hadiah), trading (perdagangan), gifting, dan sebaliknya, dengan memanfaatkan penukaran poin.

g. tantangan antar sesama pengguna

h. embedding kecil dengan aktivitas lainnya.

\section{Android}

Android adalah paket software open source yang mencakup sistem operasi, middleware, dan aplikasi mobile, bersama dengan satu set library API untuk menulis aplikasi yang dapat membentuk tampilan, rasa, dan fungsi perangkat yang mereka jalankan (Vanjire dkk. [6]).

Banyak jenis dari perangkat lunak android, saat ini trend perangkat lunak android masih dikuasai oleh perangkat lunak berjenis social media.
Hampir semua social media sudah menggunakan teknologi Location Based Service, agar mempermudah dalam mendapatkan informasi tentang keberadaan pengguna lain.

\section{Android SDK}

Aplikasi Android ditulis dalam bahasa pemrograman Java. Android SDK Tools mengkompilasi kode bersama data dan file sumber daya ke dalam APK (Paket Android), yaitu file arsip berekstensi APK. Satu file APK berisi semua konten aplikasi Android dan merupakan file yang digunakan perangkat berbasis Android untuk menginstal aplikasi (Anonim [7]).

Android SDK mencakup berbagai kakas yang membantu pengembang dalam melakukan pengembangan aplikasi mobile dengan platform android. Kakas tersebut diklasifikasikan menjadi dua kelompok, yaitu SDK Tools dan Platform Tools (Anonim [8]).

Untuk membangun sebuah perangkat lunak berbasis android, android SDK menjadi komponen yang penting. Apabila kakas yang digunakan untuk membangun perangkat lunak berbasis android ini adalah android studio maka pengembang akan mendapatkan kemudahan dengan tersedianya Android SDK dalam paket kakas. 


\section{Location Based Service}

Location Based Service (LBS) adalah layanan untuk memberikan informasi yang tersimpan dalam database. Informasi ini dapat dibuat, disusun, dipilih, atau disaring saat lokasi pengguna berpindah. Dalam setiap ponsel saat ini layanan pengiriman informasi telah menjadi sangat diperlukan. LBS memungkinkan user untuk menemukan lokasi geografis perangkat mobile berupa koordinat GPS (lintang dan bujur), dan menawarkan layanan berdasarkan informasi lokasi (Essayad [9]).

\section{Komponen Location Based Service}

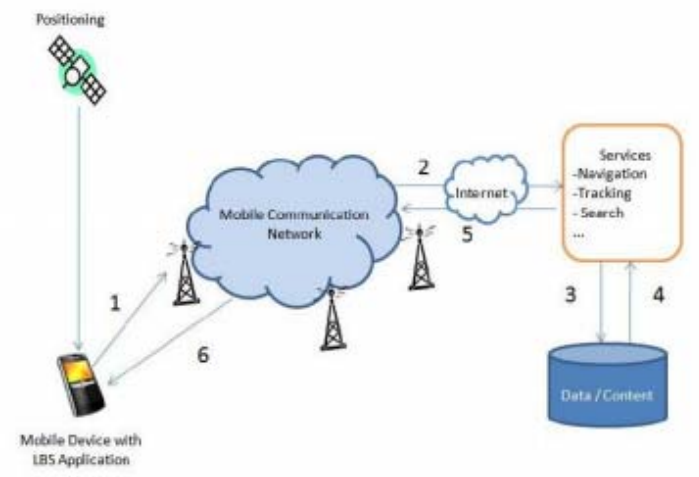

Gambar 3(b).

Komponen Utama Location Based Service [6]

Terdapat lima komponen pendukung utama dalam teknologi Layanan Berbasis Lokasi, antara lain:

1. Piranti Mobile, adalah salah satu komponen penting dalam LBS. Piranti ini berfungsi sebagai alat bantu (tool) bagi pengguna untuk meminta informasi. Hasil dari informasi yang diminta dapat berupa teks, suara, gambar dan lain sebagainya. Piranti mobile yang dapat digunakan bisa berupa PDA, smartphone, laptop. Selain itu, piranti mobile dapat juga berfungsi sebagai alat navigasi di kendaraan seperti halnya alat navigasi berbasis GPS.

2. Jaringan Komunikasi, Komponen ini berfungsi sebagai jalur penghubung yang dapat mengirimkan data-data yang dikirim oleh pengguna dari piranti mobile-nya untuk kemudian dikirimkan ke penyedia layanan dan kemudian hasil permintaan tersebut dikirimkan kembali oleh penyedia layanan kepada pengguna.

3. Komponen Positioning (Penunjuk Posisi/Lokasi), Setiap layanan yang diberikan oleh penyedia layanan biasanya akan berdasarkan pada posisi pengguna yang meminta layanan tersebut. Oleh karena itu diperlukan komponen yang berfungsi sebagai pengolah/pemroses yang akan menentukan posisi pengguna layanan saat itu. Posisi pengguna tersebut bisa didapatkan melalui jaringan komunikasi mobile atau juga menggunakan Global Positioning System (GPS).

4. Penyedia layanan dan aplikasi, merupakan komponen LBS yang memberikan berbagai macam layanan yang bisa digunakan oleh pengguna. Sebagai contoh ketika pengguna meminta layanan agar bisa tahu posisinya 
saat itu, maka aplikasi dan penyedia layanan langsung memproses permintaan tersebut, mulai dari menghitung dan menentukan posisi pengguna, menemukan rute jalan, mencari data di Yellow Pages sesuai dengan permintaan, dan masih banyak lagi yang lainnya.

5. Penyedia data dan konten, Penyedia layanan tidak selalu menyimpan seluruh data dan informasi yang diolahnya. Karena bisa jadi berbagai macam data dan informasi yang diolah tersebut berasal dari pengembang/pihak ketiga yang memang memiliki otoritas untuk menyimpannya. Sebagai contoh basis data geografis dan lokasi bisa saja berasal dari badan-badan milik pemerintah atau juga data-data perusahaan/bisnis/industri bisa saja berasal dari Yellow Pages, maupun perusahaan penyedia data lainnya.

\section{Unsur Utama Location Based Service pada Android}

Location based service pada sistem operasi android mempunyai dua unsur utama, yaitu:

1. Location Manager (API Maps): Menyediakan perangkat bagi sumber atau source untuk LBS, Application Programming Interface (API) Maps menyediakan fasilitas untuk menampilkan atau memanipulasi peta. Paket ini berada pada "com.google.android.maps;".
2. Location Providers (API Location): Menyediakan teknologi pencarian lokasi yang digunakan oleh perangkat. API Location berhubungan dengan data GPS (Global Positioning System) dan data lokasi real-time. API Location berada pada paket Android yaitu dalam paket "android.location". Lokasi, perpindahan, serta kedekatan dengan lokasi tertentu dapat ditentukan melalui Location Manager.

\section{ANALISIS DAN PERANCANGAN}

Analisis dilakukan untuk mengurai secara mendalam terhadap perancangan yang akan dilakukan. Pada perancangan perangkat lunak pemantau lokasi anak juga dilakukan analisis untuk menentukan kebutuhan/persyaratan dan perilaku perangkat lunak.

\section{Analisis Kebutuhan}

Dalam merancang sebuah perangkat lunak, dibutuhkan persyaratan- persyaratan kebutuhan yang harus dipenuhi oleh perangkat lunak. Berikut ini adalah kebutuhan-kebutuhan perangkat lunak pemantau lokasi anak.

1. Perangkat lunak dapat dihubungkan dengan facebook

2. Perangkat lunak dapat dihubungkan dengan twitter 
3. Perangkat lunak dapat mancatat nomor handphone darurat

4. Perangkat lunak dapat mengirim pesan darurat lewat sms ke nomor darurat

5. Perangkat lunak dapat mengirim pesan darurat ke facebook berupa posting status

6. Perangkat lunak dapat mengirim pesan darurat ke twitter berupa posting status

7. Perangkat lunak dapat mencari koordinat pengguna

8. Perangkat lunak dapat menampilkan posisi pengguna pada sebuah peta

9. Perangkat lunak dapat mengirim pesan darurat ke facebook, twitter, dan sms secara serentak

10.Perangkat lunak dapat mempasangkan dua akun, sebagai orang tua dan anak

11.Perangkat lunak dapat mencatat tempattempat yang aman bagi pengguna anak dari akun orang tua

12.Perangkat lunak dapat memberi notifikasi pada orang tua, jika anak keluar dari zona aman yang ditentukan, dengan radius yang ditentukan, selama lebih dari waktu yang ditentukan

\section{Fungsional Perangkat Lunak}

Kebutuhan-kebutuhan yang telah didefinisikan, kemudian digambarkan ke dalam sebuah diagram Use-Case sebagai fungsional perangkat lunak. Diagram Use Case menggambarkan interaksi yang khas antara pengguna dari perangkat lunak dengan perangkat lunak, memberikan penjelasan tentang bagaimana perangkat lunak tersebut digunakan. Diagram Use-case perangkat lunak pemantau lokasi anak dapat dilihat pada gambar 3(a).

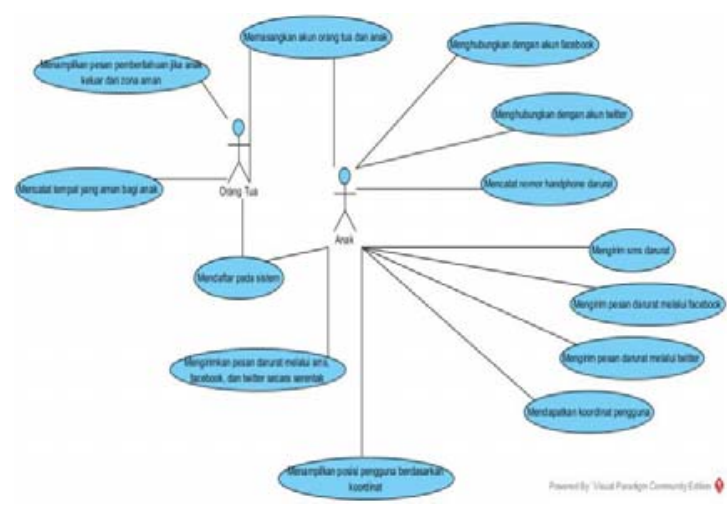

Gambar 4(a)

Use-case Diagram Deteksi Citra

\section{Perancangan Arsitektur}

Perangkat lunak pemantau lokasi anak terdiri dari dua aplikasi klien (untuk orang tua dan anak), dan satu aplikasi server (pengolah data dan pengirim notifikasi). Arsitektur perangkat lunak pemantau lokasi anak dapat dilihat pada gambar 4(b). 


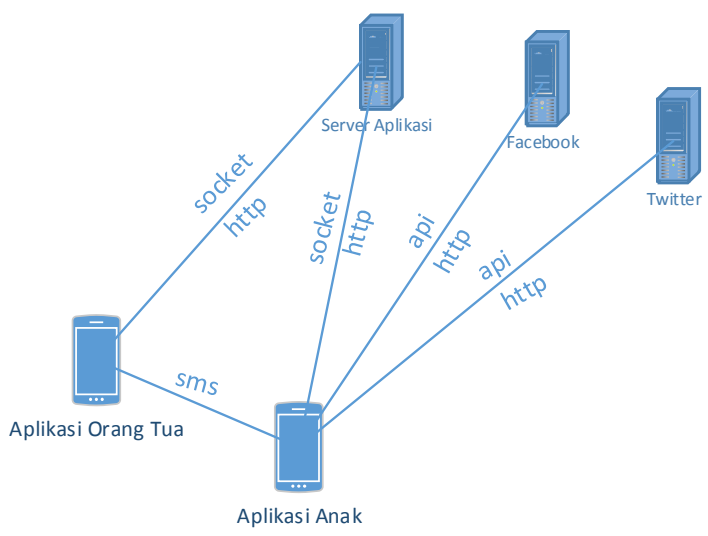

Gambar 4(b)

Arsitektur Perangkat Lunak

\section{Perancangan Antarmuka}

Perancangan antarmuka merupakan gambar rancangan tampilan antarmuka pengguna dari perangkat lunak pemantau lokasi anak yang akan dibuat. Rancangan antarmuka tersebut disesuaikan dengan ukuran dan sifat smartphone android.

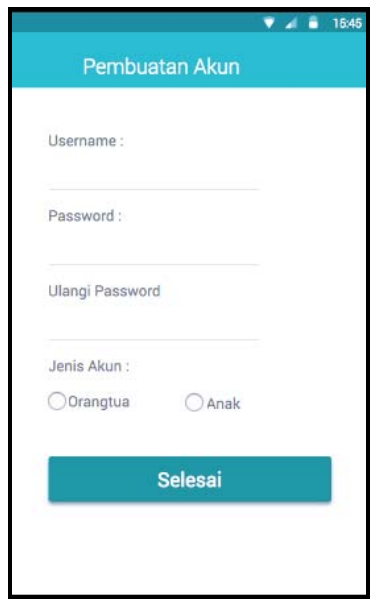

Gambar 4(c)

Antarmuka Halaman Pendaftaran

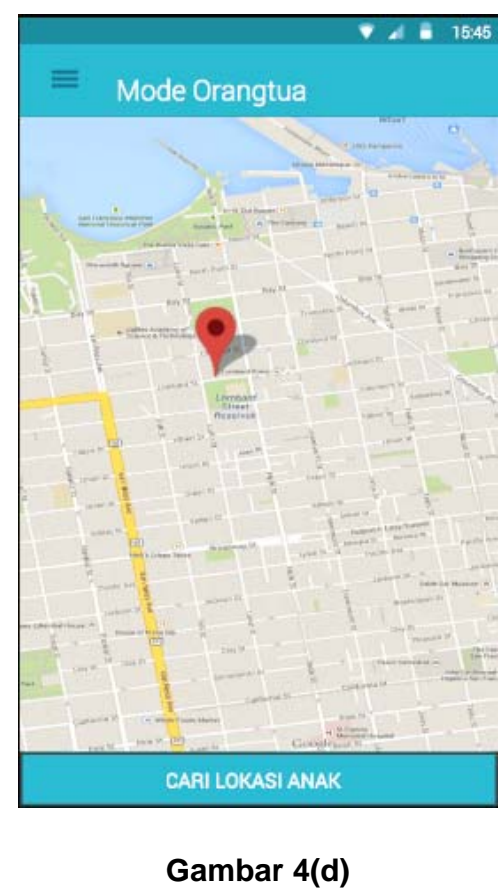

Antarmuka Halaman Posisi Anak

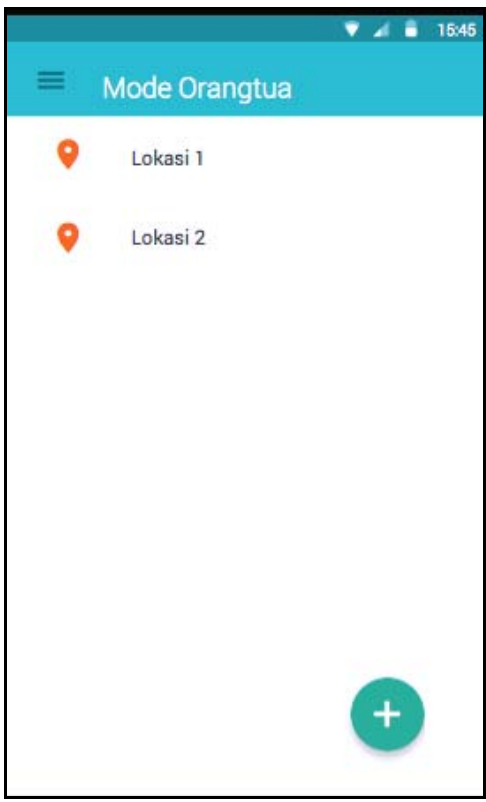

Gambar 4(e)

Antarmuka Halaman Pengelolaan Lokasi Aman Bagi Anak 


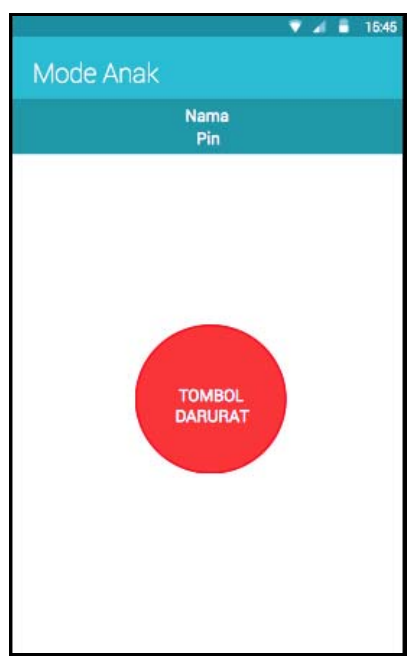

Gambar 4(f)

Antarmuka Halaman Tombol Darurat

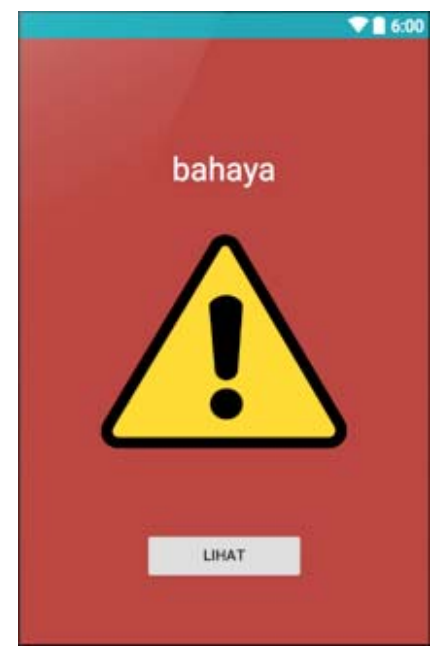

Gambar 4(g)

Antarmuka Halaman Notifikasi Bahaya

\section{Perancangan Gamifikasi}

Gamifikasi adalah sebuah konsep yang mengadopsi elemen-elemen dalam permainan (game) ke dalam sebuah kegiatan atau proses yang bukan game, pada prinsipnya gamifikasi mempunyai untuk meningkatkan retensi, atensi serta interaksi antara pengguna dengan sistem. Komponen gamifikasi terdiri dari empat buah yaitu:

i. Aturan: Sebuah tatanan yang dijadikan landasan dalam sebuah permainan, biasanya aturan ini digunakan untuk menjelaskan apa yang dapat dilakukan dan tidak dilakukan oleh pengguna.

j. Feedback: Timbal balik berupa imbalan yang didapatkan oleh pengguna ketika telah mencapai atau menyelesaikan sesuatu. Feedback biasa diasosiasikan dengan hadiah dan poin

k. Goal: Hal utama yang harus dicapai oleh pengguna, dan goal hanya dapat didefiniskan menjadi dua buah multiple dan single hanya berbeda dari sisi jumlah yang harus dicapainya, biasanya ketika pengguna berhasil mencapai goal maka sebuah game dinyatakan berakhir.

I. Challenge: Tantangan untuk menguji tingkat kemahiran pemain, dan menjadi komponen yang penting didalam pembentukan game

Berdasakan komponen tersebut, Perangkat Lunak Pemantau Lokasi Anak dibentuk dengan menggunakan pendekatan achievement gamification, dengan framework component based gamification. Adapun hasil perancangan 
gamifikasi pada Perangkat Lunak Pemantau Lokasi Anak adalah sebagai berikut:

1. Aturan

- Pemain: Pengguna dengan akun anak.

- Tema Permainan: Tema permainan pada perangkat lunak pemantau anak adalah menjadi anak yang menurut pada orang tua.

- Aksi Pemain: Mengaktifkan perangkat lunak, kemudian berusaha berada dalam jangkauan tempat yang ditentukan sebagai tempat aman oleh orang tua.

- Aturan Permainan: Poin didapatkan berdasarkan lamanya waktu yang dihabiskan di tempat yang ditentukan aman.

- Mekanik Permainan: Lebih besar poin yang didapatkan, lebih tinggi level yang disandang.

2. Goal

- Gameplay: Pemain harus berada dalam jangkauan tempat yang ditentukan selama mungkin untuk mendapatkan poin sebanyak-banyaknya.

- Objectives: Bertahan di tempat yang ditentukan aman.

3. Challenge

- Problem domain link: Mendapatkan predikat anak baik bulan ini
- Progression: Akuisisi poin tiap tingkatan berbeda. Semakin tinggi tingkatan, maka semakin tinggi juga poin yang didapat per satuan waktu tertentu.

4. Feedback

- Rewards: Poin untuk bertahan di tempat yang ditentukan aman adalah $5 \times$ level per menitnya.

\section{KESIMPULAN}

Dari hasil perancangan Perangkat Lunak Pemantau Lokasi Anak didapatkan beberapa kesimpulan. Kesimpulan yang didapatkan mencakup hasil perancangan perangkat lunak dan perancangan gamifikasi untuk perangkat lunak pemantau lokasi anak.

1. Perangkat lunak pemantau lokasi anak telah dirancang menjadi sebuah rancangan perangkat lunak yang dapat dikembangkan lebih lanjut menjadi sebuah perangkat lunak.

2. Aturan gamifikasi untuk perangkat lunak pemantau lokasi anak telah dirancang dan dapat diterapkan pada perangkat lunak pada fase konstruksi perangkat lunak.

\section{DAFTAR RUJUKAN}

[1] Maslow, Abraham, "A Theory of Human Motivation". Start Publishing LLC, 2013.

[2] , "Crime Index by Country 2015", Numbeo, 23 Maret 2015, 
http://www.numbeo.com/crime/rankings_b y_country.jsp?title=2015.

[3] , "Jumlah Tindak Pidana Menurut Kepolisian Daerah, 2000 2013", Badan Pusat Statistik, 23 Maret 2015 ,

http://www.bps.go.id/linkTabelStatis/view/i $d / 1570$.

[4] . "Persentase Penyelesaian

Tindak Pidana Menurut Kepolisian Daerah, 2000-2013", Badan Pusat Statistik, 23 Maret 2015, http://www.bps.go.id/linkTabelStatis/view/i d/15705.

[5]

\begin{tabular}{llll} 
& & & \\
\hline Gamification.org, & 15 & Mei & 2016,
\end{tabular}

[6] Vanjire, S., Kanchan, U., Shitole, G., Patil, P., "Location Based Services on
Smart Phone through the Android Application.", International Journal of Advanced Research in Computer and Communication Engineering, 2014.

[7] ( Help", Google, 10 November 2015 http://developer.android.com/int//in/tools/h elp/index.html.

[8] - "Developers Android, App Fundamentals“, Google, 10 November 2015 , http://developer.android.com/int//in/guide/ components/fundamentals.html.

[9] Essayad, Abdesslam., "Design and Implementation of a Platform for Location Based Services: a Case Study of GIS of Archaeological and Handicraft of Fez Medina”, $\quad$ Oktober 2015. 